\begin{tabular}{cc|c}
\hline Tar. Bil. Der. & Tarım Bilimleri Dergisi & Journal of Agricultural Sciences \\
& $\begin{array}{c}\text { Dergi web sayfası: } \\
\text { www.agri.ankara.edu.tr/dergi }\end{array}$ & Journal homepage: \\
& www.agri.ankara.edu.tr/journal
\end{tabular}

\title{
Bazı Yabancı Ot Mücadele Yöntemlerinin Akdeniz Bölgesi Meralarında Ot Verimi, Botanik Kompozisyon ve Ot Kalitesi Üzerine Etkisi
}

\author{
Selahattin ÇINAR ${ }^{\mathrm{a}}$, Rüştï HATİPOĞLU ${ }^{\mathrm{b}}$, Mustafa AVCI ${ }^{\mathrm{c}}$ \\ ${ }^{a}$ Gaziosmanpaşa Üniversitesi, Ziraat Fakültesi, Tarla Bitkileri Bölümü, Taşlıçiftlik, Tokat, TÜRKIYE \\ ${ }^{\boldsymbol{b}}$ Çukurova Üniversitesi, Ziraat Fakültesi, Tarla Bitkileri Bölümü, Balcall, Adana, TÜRKIYE \\ ${ }^{c}$ Doğu Akdeniz Tarımsal Araştırma Enstitüsü, Yüreğir, Adana, TÜRKIYE
}

\section{ESER BILGISİ}

Araştırma Makalesi DOI: 10.1501/Tarimbil_0000001307

Sorumlu Yazar: Selahattin ÇINAR, E-posta: scinar01@hotmail.com, Tel: +90 (530) 8499010

Geliş Tarihi:28 Kasım 2013, Düzeltmelerin Gelişi: 21 Mayıs 2014, Kabul: 05 Haziran 2014

\section{ÖZET}

Araştırma, Çukurova Bölgesi’ndeki makiliklerin tahribi sonucu ortaya çıkan kıraç meralarda yabancı otlarla etkili mücadele yöntemlerinin belirlenmesi amacıyla 2006-2009 yılları arasında Mersin ili Toroslar ilçesi Resul köyü doğal merasında yürütülmüştür. Araştırma, tesadüf blokları deneme desenine göre 3 tekrarlamalı olarak yürütülmüştür. Denemede biçme, gübreleme, 2.4-D, Picloram+2.4-D, Paraquat ve Glyphosate uygulamaları incelenmiştir. Araştırma sonuçları, gübreleme uygulamasının meranın kuru madde ve sindirilebilir kuru madde verimlerini artırdığını göstermiştir. Tüm uygulama parsellerinde kuru madde verimi, kontrol parsellerindekine göre daha yüksek olmuştur. Picloram+2.4D+gübreleme uygulaması buğdaygillerin botanik kompozisyondaki oranını artırırken baklagillerin oranını azaltmıştır. Paraquat+gübreleme uygulaması botanik kompozisyonda diğer familya bitkilerinin oranını artırmıştır. Picloram+2.4D+gübreleme uygulaması otun NDF oranını artırmıştır. Araştırmadan elde edilen bulgulara dayanarak, Çukurova bölgesindeki makilerin tahribi sonucu ortaya çıkmış meralarda çoğunluğu geniş yapraklı bitkilerden oluşan yabancı otların Picloram+2,4-D uygulamasıyla etkin bir şekilde kontrol edilebileceği, bu tip meralarda yabancı ot kontrolü ile birlikte yapılacak gübre uygulamasının meranı ot verimi ve kalitesinde artışa neden olacağı sonucuna varılmıştır. Anahtar Kelimeler: Mera; Yabanc1 ot mücadelesi; Botanik kompozisyon; Verim; Kalite

\section{Effects of Some Weed Control Methods on Hay Yield, Botanical Composition and Forage Quality of a Rangeland in the Mediterranean Region}

\author{
ARTICLE INFO \\ Research Article \\ Corresponding Author: Selahattin ÇINAR, E-mail: scinar01@hotmail.com, Tel: +90 (530) 8499010 \\ Received: 28 November 2013, Received in Revised Form: 21 May 2014, Accepted: 05 June 2014
}




\begin{abstract}
This research was conducted to determine the effective control methods for the weeds of pastures formed through the destruction of maqui vegetations in the Çukurova region. The experiment was conducted on the rangeland in the Resul Village of Toroslar District of Mersin during the years of 2006-2009. The experiment was designed according to the randomized complete block design with three replications. In the research, six different weed control methods such as cutting, fertilization, application of 2.4-D, Picloram+2.4-D, Paraquat or Glyphosate were studied. Results of the research showed that application of fertilizer increased dry matter yield and digestible dry matter yield of pasture. The highest dry matter yield and digestible dry matter was obtained from fertilizer treatments. Dry matter yields in all treatments were greater as compared to the control. Picloram+2.4-D+fertilization treatment increased ratio of grasses in botanical composition while ratio of legumes decreased compared with the other treatments. Paraquat+fertilization treatment increased ratio of other families. Picloram+2.4-D+fertilization treatment increased NDF\% content of the hay. From the results of the research, it was concluded that the weeds, generally from the families with broad leaves, on the pastures formed through degeneration of maqui vegetation in the Çukurova Region can be effectively controlled by the application of herbicide Picloram $+2,4-\mathrm{D}$, and hay yield and quality of those pastures could be increased by the fertilization together with weed control.
\end{abstract}

Keywords: Pasture; Weed control; Botanical composition; Yield; Quality

(C) Ankara Üniversitesi Ziraat Fakültesi

\section{Giriş}

Uygun olmayan kullanımlar sonucunda büyük çoğunluğu bozulan Türkiye meralarının verim güçleri ve ot kaliteleri düşmüştür (Gökkuş 1991). Türkiye genelinde olduğu gibi, Çukurova bölgesindeki meraların kullanımında da herhangi bir yönetim ilkesine uyulmaması, kontrolsüz, erken ve ağır şekilde otlatılan bu alanların bozulmasına neden olmuştur. Bulundukları bölgelere göre değişmek üzere Türkiye meralarının kuru ot verimleri 45$100 \mathrm{~kg} \mathrm{da}^{-1}$ arasında değişmektedir (Gökkuş \& Koç 2001). Akdeniz Bölgesi mera alanlarının ülke mera alanlarının \% 7.0'sini oluşturduğu ve ortalama kuru ot verimlerinin ise $60 \mathrm{~kg} \mathrm{da}^{-1}$ olduğu bildirilmiştir (Altın et al 2011). Adana yöresinde yürütülen çalışmalarda taban meralarda kuru ot veriminin $120-725 \mathrm{~kg} \mathrm{da}^{-1}$ (Çınar et al 2009), ortalama otlatma süresinin 150180 gün olduğu, taban meralarda bitki ile kaplılık oranının \% 68.9-95.9 arasında değiştiği (İnal et al 2011), bitki örtüsünde yer alan türlerin \% 10-45'ini yabancı otların oluşturduğu belirlenmiştir (Çınar et al 2003; Hatipoğlu et al 2001).

Yabanc1 ot kontrol uygulamalarının mera üzerindeki etkisi, meranın bulunduğu ekolojik koşullara, meranın durumuna, sorun oluşturan yabanc1 ot türlerine ve uygulanan yabanc1 ot kontrol yöntemine bağlı olarak farklılık göstermektedir. 2.4-D+azotlu gübre uygulaması ABD'nin Güney Dakota bölgesindeki bir merada verimi artırmıştır (Nichols \& Mc Murphy 1969). Teksas’ta yürütülen bir araştırmada ise; picloram, bromacil, dicamba, 2.4, 5-T ve bunların kombinasyonları çalı kontrolü için merada uygulandığında meranın ot veriminde önemli düzeyde artış olduğu saptanmıştır (Bovey et al 1972). Doğu Anadolu bölgesindeki bir çayırda 2.4-D uygulanan parsellerde verimlerin daha düşük olduğu, kuru ot ve ham protein verimlerinin herbisit uygulama zamanlarına bağlı olarak önemli seviyede değişmediği ancak yıllara bağlı olarak düzenli arttığ1, herbisit uygulamasından sonra kompozisyondaki buğdaygillerin oranının arttığ1, diğer familya türlerinin ve baklagillerin oranının azaldığı belirlenmiştir (Gökkuş \& Koç 1996). Doğu Anadolu bölgesindeki bir merada yürütülen araştırmada; bitki örtüsündeki yabanc1 otlar1 kontrol etmek amaciyla 2.4-D li herbisitlerin kullanılabileceği, yabanc1 ot populasyonuna göre herbisit uygulamalarının bir ya da birkaç yıl uygulanması gerektiği, merada arzulanan bitkilerin fizyolojik olarak güçlenmesi ve üretkenliklerinin artırabilmesi için gübrelemenin mutlak gerektiği, bu amaçla dekara $7.5 \mathrm{~kg}$ N'un yeterli olabileceği, 
gübre uygulamasının her yıl tekrarlanması gerektiği sonucuna varılmıştır (Özaslan 1996).

Karadeniz bölgesindeki bir merada yürütülen çalışmada; biçim ve herbisit uygulamasının meranın kuru ot ve ham protein verimi üzerine y1llara göre farklı etkide bulunduğu, üç yıllık ortalama sonuçlara göre en düşük kuru ot veriminin kontrol parsellerinden sağlanırken, en yüksek kuru ot veriminin gübreleme + üstten tohumlama + havalandırma işlemlerinin birlikte uygulandığ bildirilmektedir (Aydın \& Uzun 2000). ABD'nin batısındaki meralar üzerinde yapılan bir araştırmada; 2.4-D uygulamasının buğdaygil yem bitkilerini artırdığ 1 , hektara 0.6 kg'dan daha yüksek dozlarda uygulanan 2.4-D'nin ise gelin düğmesi bitkisini (Centaurea maculasa) \% 75 oranında azalttığ saptanmıştır (Jacobs \& Sheley 1999). Montana'da iki lokasyonda iki yıl süreyle yürütülen bir araştırmada; picloram uygulamasının $\mathrm{m}^{2}$ deki gelin düğmesi sayısını önemli derecede azalttığı $\left(<5\right.$ bitki $\left.\mathrm{m}^{-2}\right)$, dicamba+2.4-D karışımının bitkiler sapa kalkma ve tomurcuk döneminde iken uygulandığında daha etkili olduğu, sonbaharda ve ilkbaharda rozet formunda iken uygulandığında ise en düşük etkiyi gösterdiği, benekli gelin düğmesi (Centaurea maculasa)'nin kontrolü açısından, picloram ve clopyralid +2.4 D‘nin dicamba + 2.4-D karışımından daha etkili olduğu, dicamba+2.4-D, clopyralid+2.4-D ve picloram uygulamalarının çok yıllık buğdaygil yem bitkilerinin verimini kontrole göre yükselttiği saptanmıştır (Roger et al 2000). Çukurova bölgesinin taban meralarında yürütülen bir araştırmada; fosforlu gübre ile birlikte uygulanan azot dozlarının mera veriminde artış, vejetasyondaki baklagil ve diğer familya bitkilerinin mera verimine katılma oranında azalma, buğdaygil oranında ise artışa neden olduğu saptanmıştır (Hatipoğlu et al 2001).

Çukurova bölgesi geçit kesimi meralarında yapılan vejetasyon etüdü çalışmalarında bitki ile kaplılık oranının \%92.0 olduğu, bitki ile kaplı alanda yabancı otların oranının \% 58.7 olduğu, yabanc1 otlardan yüksek oranda bulunanların ise sırasıyla mavi çakır dikeni (\% 26.0), andız otu (\% 10.0), murt çalısı (\% 8.1), kangal (\% 7.9) olduğu belirlenmiştir (Çınar et al 2011).
$\mathrm{Bu}$ araştırma, Çukurova bölgesindeki makiliklerin tahribi sonucu oluşmuş kıraç meralarda yer alan mavi çakır dikeni, andız otu, murt çalısı ve kangal gibi yabancı otlara karşı uygulanabilecek mücadele yöntemlerinin, meranın botanik kompozisyon, ot verimi ve ot kalitesi üzerine etkilerinin belirlenmesi amacıyla yapılmıştır.

\section{Materyal ve Yöntem}

Araştırma; deniz seviyesinden yükseltisi 450 m. olan Mersin ili Toroslar ilçesi Resul köyü merasinda $\left(36^{\circ}, 90^{\prime}\right.$ Kuzey enlemleri, 34ㅇ, 58' Doğu boylamları) 2006-2009 yılları arasında üç yıl süre ile yürütülmüştür. Meradaki yaygın olan mera yabancı ot türlerinin dikensi türlerden mavi çakırdikeni (Eryngium creticum), çalımsı türlerden andız otu (Dittrichia viscosa) ve murt çalısı (Myrtus communis) olduğu saptanmıştır (Çınar et al 2011).

Denemenin yürütüldüğü Mersin ili Toroslar ilçesi Resul köyü'ne en yakın meteoroloji istasyonu olan Mersin ili Meteoroloji İstasyonu'nun verilerine göre deneme yılları ve uzun yıllar ortalaması ile ilgili bazı aylık verileri Çizelge 1'de verilmiştir. Çizelgede izlendiği gibi, deneme yıllarında ortalama sıcaklık $\left(20.3^{\circ} \mathrm{C}, 20.3^{\circ} \mathrm{C}\right.$, ve $\left.20^{\circ} \mathrm{C}\right)$ uzun yıllar ortalamasina $\left(19.2^{\circ} \mathrm{C}\right)$ göre daha yüksek gerçekleşmiş, 2007 ve 2008 yıllarında yıllık yağış toplamı $(574 \mathrm{~mm}$ ve $327 \mathrm{~mm}$ ) uzun yillar ortalamasına $(588.7 \mathrm{~mm})$ göre daha düşük, 2009 yılında $(836 \mathrm{~mm})$ ise uzun yıllar ortalamasına göre daha yüksek olmuş, deneme yıllarında nispi nem ortalaması (\% 62.5 , \% 62.9 ve $\%$ 64.4) uzun yıllar ortalamasına ( $\%$ 69.2) göre daha düşük gerçekleşmiştir (MDM 2009). Deneme alanı topraklarının killi, tuzsuz, hafif alkali, kireç yönünden zengin, organik maddece yeterli, fosfor, çinko ve kireç seviyesinin yetersiz olduğu belirlenmiştir (TBLK 2007).

Araştırma ile ilgili deneme, tesadüf blokları deneme desenine göre 3 tekrarlamalı olarak yürütülmüştür. Parsel büyüklüğü 4 x $5=20 \mathrm{~m}^{2}$ olarak alınmıştır. Uygulama etkilerinin birbirine karışmaması amacıyla iki uygulama parseli arasında $1 \mathrm{~m}$ boşluk bırakılmıştır. Buna göre bir blok alanı (7 uygulama x 4 $\mathrm{m}$ parsel genişliğ $\mathrm{i}=28 \mathrm{~m}+$ her bir parsel arası mesafe 
Çizelge 1- Mersin ili 2007, 2008, 2009 yılları ve uzun yıllar, aylık iklim değerleri ortalaması (MDM 2009) Table 1-Long years average values as well as in the years 2007, 2008 and 2009 of monthly climatical data for the province Mersin (MDM 2009)

\begin{tabular}{|c|c|c|c|c|c|c|c|c|c|c|c|c|}
\hline \multirow[b]{2}{*}{ Aylar } & \multicolumn{4}{|c|}{ Ortalama sıcaklık $\left({ }^{\circ} \mathrm{C}\right)$} & \multicolumn{4}{|c|}{ Toplam yağış (mm) } & \multicolumn{4}{|c|}{ Nispi nem (\%) } \\
\hline & $\begin{array}{l}\text { Uzun } \\
\text { y1llar }\end{array}$ & 2007 & 2008 & 2009 & $\begin{array}{l}\text { Uzun } \\
\text { y1llar }\end{array}$ & 2007 & 2008 & 2009 & $\begin{array}{l}\text { Uzun } \\
\text { yllar }\end{array}$ & 2007 & 2008 & 2009 \\
\hline Ocak & 10.6 & 11.0 & 9.0 & 11.0 & 97.9 & 8.0 & 40.0 & 172.0 & 66.6 & 58.0 & 51.0 & 61.0 \\
\hline Şubat & 11.0 & 13.0 & 11.0 & 12.0 & 78.6 & 106.0 & 32.0 & 135.0 & 66.5 & 64.0 & 55.0 & 67.0 \\
\hline Mart & 13.7 & 15.0 & 17.0 & 13.0 & 50.2 & 75.0 & 8.0 & 98.0 & 67.9 & 63.0 & 63.0 & 61.0 \\
\hline Nisan & 17.5 & 17.0 & 19.0 & 18.0 & 38.3 & 6.0 & 18.0 & 12.0 & 71.4 & 60.0 & 69.0 & 65.0 \\
\hline Mayıs & 21.5 & 23.0 & 22.0 & 22.0 & 23.0 & 81.0 & 32.0 & 28.0 & 73.4 & 70.0 & 71.0 & 65.0 \\
\hline Haziran & 25.0 & 26.0 & 26.0 & 27.0 & 10.4 & 0.0 & 3.0 & 0.0 & 75.7 & 68.0 & 70.0 & 68.0 \\
\hline Temmuz & 27.8 & 29.0 & 29.0 & 29.0 & 8.7 & 7.0 & 0.0 & 2.0 & 76.5 & 67.0 & 71.0 & 72.0 \\
\hline Ağustos & 28.2 & 29.0 & 30.0 & 29.0 & 5.3 & 1.0 & 4.0 & 0.0 & 74.1 & 69.0 & 74.0 & 64.0 \\
\hline Eylül & 25.7 & 27.0 & 27.0 & 26.0 & 8.3 & 0.0 & 14.0 & 12.0 & 66.7 & 61.0 & 68.0 & 63.0 \\
\hline Ekim & 21.6 & 24.0 & 23.0 & 24.0 & 43.8 & 2.0 & 25.0 & 23.0 & 62.7 & 51.0 & 56.0 & 54.0 \\
\hline Kasım & 15.8 & 17.0 & 18.0 & 16.0 & 89.1 & 124.0 & 78.0 & 126.0 & 63.8 & 55.0 & 56.0 & 63.0 \\
\hline Aralık & 11.7 & 12.0 & 12.0 & 13.0 & 135.0 & 164.0 & 73.0 & 228.0 & 65.4 & 64.0 & 51.0 & 70.0 \\
\hline Top/Ort. & 19.2 & 20.3 & 20.3 & 20.0 & 588.7 & 574.0 & 327.0 & 836.0 & 69.2 & 62.5 & 62.9 & 64.4 \\
\hline
\end{tabular}

1 metre boşluk toplamda $6 \mathrm{~m}, 28 \mathrm{~m}+6 \mathrm{~m}=34$ metre blok uzunluğu, parsel eni $5 \mathrm{~m}$ x blok uzunluğu $34 \mathrm{~m}$ ) $170 \mathrm{~m}^{2}$, bloklar arası mesafe ise $2.5 \mathrm{~m}$ 'dir. Denemede biçme+gübreleme, gübreleme, 2.4-D+gübreleme, Picloram+2.4-D+gübreleme, Paraquat+gübreleme ve Glyphosate+gübreleme uygulamaları denenmiştir. Ayrıca, hiçbir uygulamanın yapılmadığı kontrol parselleri oluşturulmuştur. Biçme işlemi, yabancı otların depo organlarında yedek besin maddelerinin en düşük düzeyde bulunduğu tomurcuklanma veya ilk çiçeklenmenin başladığı zamanda yapılmıştır (Altın 1992).

Kontrol uygulaması dışındaki diğer tüm uygulama parsellerine $5 \mathrm{~kg} \mathrm{da}^{-1}$ saf fosfor, $10 \mathrm{~kg} \mathrm{da}^{-1}$ saf azot gübresi uygulanmıştır (Tükel et al 1996; Altın et al 2005). Fosfor gübrelemesi sonbaharda, azot gübrelemesi ise erken ilkbaharda yapılmıştır. Herbisit olarak 2.4-D Amin (320 $\left.\mathrm{ml} \mathrm{da}^{-1}\right)$, Picloram+2.4-D Amin (100 ml da $\left.{ }^{-1}\right)$, Paraquat (500 $\left.\mathrm{ml} \mathrm{da}^{-1}\right)$ ve Glyphosate $\left(1500 \mathrm{ml} \mathrm{da}^{-1}\right)$ kullanılmışıtır. 2.4-D ve Picloram+2.4-D uygulamaları, söz konusu uygulama parsellerinin tamamina, Paraquat ve Glyphosate uygulamaları ise spot olarak hedef bitkilere uygulanmıştır (Darrell et al 2005). Herbisit uygulamaları 1 ve 2. y1l yabanc1 otların 3-5 yapraklı olduğu dönemde bir kez uygulanmış, 3. y1l ise uygulama yapılmamıştır (Altın 1992).

Deneme parsellerinde baskın bitki grubu olan buğdaygillerin başaklanma veya salkım çıkarma döneminde her parselde tesadüfi olarak yerleştirilen 4'er adet $0.50 \mathrm{~m}^{2}$ 'lik çerçevenin her birindeki ot $5 \mathrm{~cm}$ anız kalacak şekilde hasat edildikten sonra; buğdaygiller, baklagiller, diğer familya bitkileri olarak ayrılmıştır. Hayvanlar tarafından tercih edilmeyen türler verime dahil edilmemiştir. Her bitki grubuna ait ot örnekleri $78^{\circ} \mathrm{C}$ 'de 24 saat kurutularak, her bitki grubunun ağırlığa göre botanik kompozisyondaki oranı saptanmıştır. Her bitki grubunun ot örnekleri değirmende öğütüldükten sonra, ögütülmüş ottan alınan 2'şer gr'lık örnekler $105{ }^{\circ} C^{\circ}$ 'de 24 saat süreyle kurutularak örneklerin kuru madde oranları belirlenmiştir (Bulgurlu \& Ergül 1978). Bir parseldeki 
kuru ot için saptanan kuru madde oranı değeri, söz konusu parseldeki kuru ot verimi ile çarpılarak kuru madde verimi hesaplanmıştır.

Öğ̈̈̈ülen her bir bitki grubuna ait ot örneklerinde Kjeldahl yöntemiyle azot tayini yapılmıştır. Belirlenen azot değerleri 6.25 dönüşüm katsayısı ile çarpılarak söz konusu bitki grubuna ait ot örneğindeki \% ham protein değeri saptanmıştır (TAN 1995). NDF ve ADF içerikleri ise ANKOM 220 Fiber Analyzer cihazı kullanılarak ANKOM (2009) tarafindan açıklanan yöntemlere göre analiz edilmiştir. Her uygulama parselindeki otun ham protein oran1, ADF oran1, NDF oranının hesaplanmasında; her parselde bitki gruplarının ağırlığa göre botanik kompozisyondaki oranları söz konusu bitki grupları için saptanan ham protein oranı, ADF ve NDF değerleri ile çarpılmış ve elde edilen rakamların toplamı söz konusu parseldeki otun ham protein oran1, ADF ve NDF oranı olarak kaydedilmiştir. Ham protein oranları ile dekara kuru madde verimleri çarpılarak dekara ham protein verimleri hesaplanmıştır. Sindirilebilir kuru madde oranı (SKMO) Sheaffer et al (1995)'a göre hesaplanmıştır.

$$
\mathrm{SKMO}=88.9-(0.779 \times \% \mathrm{ADF})
$$

Sindirilebilir kuru madde oranı değerleri kuru madde verimi değerleri ile çarpılarak sindirilebilir kuru madde verimleri hesaplanmıştır.

Araştırmadan elde edilen verilere MSTAT-C istatistik paket programı kullanılarak üç tekrarlamalı tesadüf blokları deneme desenine göre varyans analizi uygulanmıştır. Varyans analizi sonuçlarına göre istatistiksel olarak önemli çıkan faktör ortalamaları Duncan $(\mathrm{P} \leq 0.05)$, y1l ortalamaları ise LSD $(\mathrm{P} \leq 0.05)$ testi ile karşılaştırılmıştır (Düzgüneş et al 1987).

\section{Bulgular ve Tartışma}

\subsection{Uygulamaların meranin botanik kompozisyona etkisi}

Uygulamalar ve yıllar meranın buğdaygil, baklagil, diğer familya bitkileri oranlarında, buğdaygil x yıl, baklagil x yıl interaksiyonunda istatistiksel olarak önemli, diğer familya $\mathrm{x}$ yıl interaksiyonunun istatistiksel olarak önemli olmadığ belirlenmiştir (Çizelge 2). Çizelge 2'de izlendiği gibi, üç yıllık ortalamalara göre buğdaygillerin vejetasyonun ağırlığa göre botanik kompozisyonuna katılma oranı uygulamalara bağlı olarak $\% 55.9$ ile \% 98.9 arasında değişmiştir. 2.4-D+gübreleme ve Picloram+2.4-D+gübreleme uygulamalarında buğdaygillerin vejetasyonun verimine katılma oranı kontroldekine göre istatistiksel olarak önemli derecede daha yüksek olmuştur. Bu sonuç, Nichols \& Mc Murphy (1969), Thilenius et al (1974), Gökkuş \& Koç (1996), Gonzalez et al (1997) ve Roger et al (2000)'in bulguları ile uyum içindedir. Geniş yapraklı bitkilere karşı etkili olan bu herbisitler uygulandığında, vejetasyondaki geniş yapraklı bitkilerin etkilenmesi ile buğdaygillerin rekabet güçlerinin artması ve vejetasyonun verimine daha fazla katkıda bulunmaları beklenen bir sonuçtur (Vallentine 1989). Üçüncü yılda buğdaygillerin oranı diğer yıllara göre genellikle daha düşük düzeyde kalmıştır. Bu duruma neden olarak üçüncü y1l çoğunluğu bir yıllık bitkilerden oluşan baklagil bitkilerinin yağış koşullarının diğer yıllara göre daha iyi olması nedeniyle vejetasyonda daha fazla oranda yer almaları gösterilebilir.

Üç yıllık ortalamalara göre, baklagillerin vejetasyonun verimine katılma oranı ortalamaları, uygulamalara bağlı olarak \% 0.8 ile $\% 18.4$ arasında değişmiştir (Çizelge 2). Paraquat+gübreleme dışındaki tüm uygulamalar baklagillerin vejetasyonun kuru madde verimine katılma oranında kontrole göre istatistiksel olarak önemli derecede azalmaya neden olmuştur. Paraquatın kontakt etkili total herbisit olması nedeniyle, toprak üstü organları zarar gören baklagiller daha sonra tekrar sürgün verebilmektedir. Buna karşl1ık, sistemik total herbisit olan Glyphosate bitkiyi tamamen öldürmektedir. 2.4-D ve Picloram+2.4-D ise geniş yapraklılarda sistemik etki eden herbisitlerdir ve bu nedenle söz konusu uygulama parsellerinde baklagil oranının düşük olması beklenen bir sonuçtur (Vallentine 1989). Nitekim Gökkuş \& Koç (1996) da 2.4-D uygulamasının merada buğdaygil oranını artırırken baklagil ve diğer familya türlerinin oranını azalttığını saptamışlardır. Biçim+gübreleme 
Çizelge 2- Farklı yabancı ot kontrol metotları uygulanan merada saptanan buğdaygil, baklagil ve diğer familyalara ait bitkilerin vejetasyonun kuru madde verimine katılma oranı ortalamaları (\%)

Table 2- Averaged ratios of legumes, grases, and otherfamily plants in the drey matter yield of a rangeland depending on the weed control method

\begin{tabular}{|c|c|c|c|c|c|c|c|c|c|c|c|c|}
\hline \multirow{2}{*}{ Uygulama } & \multicolumn{4}{|c|}{ Buğdaygil } & \multicolumn{4}{|c|}{ Baklagil } & \multicolumn{4}{|c|}{ Diğer familya } \\
\hline & 1.yll & 2.yll & 3.ysl & Ort. & 1.ysl & 2.ysl & 3.ysl & Ort. & 1.ysl & 2.yll & 3.ysl & Ort. \\
\hline Kontrol & 67.0 & 66.0 & 57.7 & $63.6 \mathrm{~cd}$ & $16.7 \mathrm{a}$ & 6.7 & 32.0 & $18.4 \mathrm{a}$ & 16.6 & 27.1 & $10.1 \mathrm{bc} *$ & $17.9 \mathrm{ab}$ \\
\hline Biçim+gübre & 82.0 & 84.0 & 78.3 & $81.4 \mathrm{abc}$ & $10.3 \mathrm{ab}$ & 2.0 & 15.7 & $9.3 \mathrm{bc}$ & 7.7 & 14.0 & $6.2 \mathrm{bc}$ & $9.3 \mathrm{bc}$ \\
\hline Gübre & 79.0 & 88.0 & 73.0 & $80.0 \mathrm{abc}$ & $11.7 \mathrm{a}$ & 4.7 & 15.3 & $10.6 \mathrm{bc}$ & 9.6 & 4.0 & $11.6 \mathrm{bc}$ & $8.4 \mathrm{bc}$ \\
\hline 2.4-D+gübre & 94.0 & 98.7 & 88.7 & $93.8 \mathrm{ab}$ & $2.7 \mathrm{bc}$ & 0.0 & 8.7 & $3.8 \mathrm{~cd}$ & 2.9 & 1.4 & $2.5 \mathrm{bc}$ & $2.3 \mathrm{c}$ \\
\hline $\mathrm{Pic}+2.4-\mathrm{D}+$ gübre & 99.3 & 99.3 & 98.0 & $98.9 \mathrm{a}$ & $0.0 \mathrm{c}$ & 0.0 & 2.0 & $0.8 \mathrm{~d}$ & 0.5 & 0.3 & $0.0 \mathrm{c}$ & $0.3 \mathrm{c}$ \\
\hline Paraquat+ gübre & 68.0 & 46.7 & 53.0 & $55.9 \mathrm{~d}$ & $11.3 \mathrm{a}$ & 5.0 & 32.0 & $16.1 \mathrm{ab}$ & 21.2 & 48.3 & $14.9 \mathrm{~b}$ & $28.1 \mathrm{a}$ \\
\hline Glyphosate+gübre & 80.0 & 84.3 & 60.0 & $74.8 \mathrm{bcd}$ & $10.7 \mathrm{ab}$ & 2.3 & 12.0 & $8.3 \mathrm{bcd}$ & 9.2 & 13.2 & $28.2 \mathrm{a}$ & $16.9 \mathrm{ab}$ \\
\hline Ortalama & $81.3 \mathrm{~A}^{+}$ & $81.0 \mathrm{~A}$ & $72.7 \mathrm{~B}$ & 78.3 & $9.0 \mathrm{~B}+$ & $3.0 \mathrm{C}$ & $16.8 \mathrm{~A}$ & 9.6 & 9.7 & 15.5 & 10.5 & 11.9 \\
\hline
\end{tabular}

*, aynı sütün içerisinde benzer harf ile gösterilen ortalamalar $\mathrm{P} \leq 0.05$ hata sınırları içerisinde Duncan testine göre birbirinden istatistiksel olarak farksızdır; +, aynı satır içerisinde benzer harf ile gösterilen ortalamalar $\mathrm{P} \leq 0.05$ hata sınırları içerisinde LSD testine göre birbirinden istatistiksel olarak farksızdır

uygulamasında baklagil oranının azalması ise, söz konusu uygulama parsellerinde yabanc1 ot mücadelesi amacıyla erken dönemde yapılan biçim nedeniyle çoğunluğu bir yıllık olan baklagillerin tohum bağlayamamasından kaynaklanmış olabilir. Gübreleme uygulamasında baklagillerin oranının azalmasının nedeni ise, özellikle azotlu gübreleme sonucu buğdaygil rekabetinin artmas1 olabilir (Bakır 1985). Denemenin ikinci yılında baklagil oranı ortalaması birinci yıla göre önemli derecede azalma göstermiş, üçüncü yılda ise her iki yıldan istatistiksel olarak önemli derecede daha yüksek olmuştur. Baklagillerin vejetasyonun verimine katılma oranında yıllar bağlı olarak ortaya çıkan bu değişimin yıllar arasındaki iklim farklılığ ve özellikle yağış miktarındaki farklılıktan kaynaklandığı söylenebilir.

Üç y1llık ortalamalara göre diğer familya bitkilerinin botanik kompozisyondaki oranı, uygulamalara bağlı olarak \% 0.3 ile \% 28.1 arasında değişmiştir (Çizelge 2). 2.4-D+gübreleme ve Picloram+2.4-D+gübreleme uygulamaları diğer familya bitkilerinin vejetasyonun verimine katılma oranında kontrole göre istatistiksel olarak önemli derecede azalmaya neden olmuştur. $\mathrm{Bu}$ sonuç,
Thilenius et al (1974) ve Gökkuş \& Koç (1996)'un bulguları ile uyum içindedir. En yüksek diğer familya bitkileri oranı ise Paraquat+gübreleme uygulama parsellerinde saptanmıştır. Paraquatın, kontakt etkili total herbisit olması nedeniyle, toprak üstü organları zarar gören diğer familya türlerinin daha sonra sürgün vermesi bunun nedeni olarak gösterilebilir (Altın et al 2005). Diğer familya türlerinin botanik kompozisyondaki oranı yıllara bağlı olarak önemli bir farklılık göstermemiştir.

\subsection{Uygulamalarin meranin kuru madde verimine etkisi}

Uygulamalar ve yıllar ile uygulama $x \quad y 1 l$ interaksiyonunun istatistiksel olarak önemli olduğu ortaya çıkmıştır (Çizelge 3). Çizelge 3'de izlendiği gibi, araştırmanın üçüncü yılında birinci ve ikinci yıllara göre istatistiksel olarak önemli derecede daha yüksek kuru madde verimi ortalaması saptanmıştır. Üçüncü yılda deneme alanına düşen yağış miktarının uzun yıllar ortalamasına ve diğer iki deneme yılına göre daha yüksek olması bu yıldaki yüksek kuru madde verimi ortalamasının nedeni olarak görülebilir. 
Denemenin birinci yllında gübreleme, 2.4-D+ gübreleme ve biçme+gübreleme uygulamaları kontrole göre kuru madde veriminde istatistiksel olarak önemli derecede artış sağlamıştır. 2,4-D+gübreleme uygulamasını kuru madde veriminde artış sağlaması ile ilgili sonuç Nichols \& Murphy (1969)'nin bulgularını desteklemektedir. Glyphosate+gübreleme uygulaması ise meranın kuru madde veriminde istatistiksel olarak önemli derecede azalmaya neden olmuştur. Sistemik total herbisit olan Glyphosate'ın spot olarak uygulanmış olmasına karşılık uygulanan alandaki tüm bitkileri etkilemesi sonucu meranın kuru madde veriminde azalmaya yol açması beklenen bir sonuçtur (Aydın \& Uzun 2000) . Denemenin ikinci yılında total herbisitler dışındaki uygulamalar kuru madde veriminde kontrole göre önemli derecede artışa neden olmuştur. Denemenin üçüncü yılında ise, uygulamalara bağlı olarak kuru madde verimi 114.7 $\mathrm{kg} \mathrm{da}^{-1}$ ile $330.3 \mathrm{~kg} \mathrm{da}^{-1}$ arasında değişmiş, ancak bu değişimin önemli olmadığı ortaya çıkmıştır.

Üç yıllık kuru madde verimi ortalamaları incelendiğinde, biçim+gübreleme, gübreleme, 2.4-D+gübreleme ve Picloram+2.4-D+gübreleme uygulamalarında kontrole göre istatistiksel olarak önemli derecede daha yüksek kuru madde verimi saptanmıştır. Paraquat+gübreleme ve Glyphosate+gübreleme uygulama parsellerinde saptanan kuru madde verimi ortalamaları kontrol parsellerinde saptanan ortalama kuru madde veriminden istatistiksel olarak farksız olmuştur. Paraquat ve Glyphosate uygulanan parsellerde verimin düşük olmasının nedeni olarak, spot olarak uygulanmış olan bu herbisitlerin yabancı of niteliğindeki türler yanında bu türlerin yakınındaki bitki türlerini de olumsuz yönde etkilemeleri gösterilebilir (Gökkuş \& Koç 1996).

Geniş yapraklılara karşı etkili herbisit olan 2.4-D+gübreleme ve 2.4-D+Picloram+gübreleme uygulamalarının meranın kuru madde verimini artırması ile ilgili bulgular dicamba+2.4-D, clopyralid+2.4-D ve picloram uygulamalarının verimi iki kattan fazla artırdığını bildiren Roger et al (2000)'ın bulguları ile uyum içindedir.

\subsection{Uygulamaların meranın ham protein oranına etkisi}

Uygulamalar ve yıllar ile bunların interaksiyonu ham protein oranında istatistiksel olarak önemli fark yaratmıştır. (Çizelge 3). Üç yıllık ortalamalara

Çizelge 3- Farklı yabancı ot kontrol metodları uygulanan merada saptanan kuru madde verimi(kg da $\left.\mathbf{~}^{-1}\right)$, ham protein oranı (\%) ve ham protein verimi $\left(\mathrm{kg} \mathrm{da}^{-1}\right)$ ortalamaları

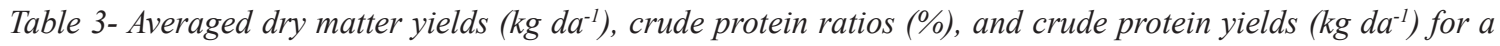
rangeland depending on the weed control method

\begin{tabular}{|c|c|c|c|c|c|c|c|c|c|c|c|c|}
\hline \multirow{2}{*}{ Uygulama } & \multicolumn{4}{|c|}{ Kuru madde verimi $\left(\mathrm{kg} \mathrm{da^{-1 } )}\right.$} & \multicolumn{4}{|c|}{ Ham protein oranı (\%) } & \multicolumn{4}{|c|}{ Ham protein verimi $\left(\mathrm{kg} \mathrm{da^{-1 } )}\right.$} \\
\hline & 1.ysl & 2.ysl & 3.ysl & Ort. & 1.ysl & 2.ysl & 3.yll & Ort. & 1.ysl & 2.yll & 3.yll & Ort. \\
\hline Kontrol & $101.4 \mathrm{c}^{*}$ & $31.7 \mathrm{~b}$ & 114.7 & $82.6 \mathrm{c}$ & $10.5 \mathrm{c}$ & 11.6 & $10.8 \mathrm{a}$ & $11.0 \mathrm{~b}$ & $10.6 \mathrm{~cd}$ & $3.8 \mathrm{~b}$ & 12.6 & $9.1 \mathrm{c}$ \\
\hline Biçim+gübre & $152.1 \mathrm{ab}$ & $210.0 \mathrm{a}$ & 220.7 & $194.3 \mathrm{ab}$ & $12.9 \mathrm{~b}$ & 13.0 & $9.2 \mathrm{abc}$ & $11.7 \mathrm{ab}$ & $19.7 \mathrm{ab}$ & $27.4 \mathrm{a}$ & 19.8 & $22.3 \mathrm{a}$ \\
\hline Gübre & $181.1 \mathrm{a}$ & $187.3 \mathrm{a}$ & 279.3 & $215.9 \mathrm{a}$ & $13.3 \mathrm{~b}$ & 11.9 & $9.8 \mathrm{ab}$ & $11.7 \mathrm{ab}$ & $24.0 \mathrm{a}$ & $22.7 \mathrm{a}$ & 27.2 & $24.6 \mathrm{a}$ \\
\hline 2.4-D+gübre & $183.0 \mathrm{a}$ & $166.8 \mathrm{a}$ & 219.0 & $189.6 \mathrm{ab}$ & $12.9 \mathrm{~b}$ & 12.3 & $8.5 \mathrm{bc}$ & $11.3 \mathrm{~b}$ & $23.8 \mathrm{a}$ & $20.4 \mathrm{a}$ & 18.6 & $20.9 \mathrm{abc}$ \\
\hline Pic+2.4-D+gübre & $121.3 \mathrm{bc}$ & $170.2 \mathrm{a}$ & 330.3 & $207.3 \mathrm{a}$ & $14.0 \mathrm{~b}$ & 13.3 & $7.9 \mathrm{c}$ & $11.7 \mathrm{ab}$ & $16.9 \mathrm{abc}$ & $22.8 \mathrm{a}$ & 26.2 & $21.9 \mathrm{abc}$ \\
\hline Paraquat+gübre & $81.2 \mathrm{~cd}$ & $23.7 \mathrm{~b}$ & 245.0 & $116.6 \mathrm{bc}$ & $15.3 \mathrm{a}$ & 12.5 & $9.5 \mathrm{abc}$ & $12.4 \mathrm{a}$ & $12.3 \mathrm{bcd}$ & $4.5 \mathrm{~b}$ & 23.8 & $13.5 \mathrm{abc}$ \\
\hline Glyphosate+gübre & $49.0 \mathrm{~d}$ & $33.2 \mathrm{~b}$ & 217.3 & $99.8 \mathrm{c}$ & $15.2 \mathrm{a}$ & 13.5 & $8.7 \mathrm{bc}$ & $12.5 \mathrm{a}$ & $7.6 \mathrm{~d}$ & $4.9 \mathrm{~b}$ & 18.8 & $10.4 \mathrm{bc}$ \\
\hline Ortalama & $124.1 \mathrm{~B}^{+}$ & $117.6 \mathrm{~B}$ & $232.3 \mathrm{~A}$ & 158.0 & $13.4 \mathrm{~A}^{+}$ & $12.6 \mathrm{~A}$ & $9.2 \mathrm{~B}$ & 11.7 & $16.4 \mathrm{AB}$ & $15.2 \mathrm{~B}$ & $21.0 \mathrm{~A}$ & 17.5 \\
\hline
\end{tabular}

*, aynı sütün içerisinde benzer harf ile gösterilen ortalamalar $\mathrm{P} \leq 0.05$ hata sınırları içerisinde Duncan testine göre birbirinden istatistiksel olarak farksızdır; +, aynı satır içerisinde benzer harf ile gösterilen ortalamalar $\mathrm{P} \leq 0.05$ hata sınırları içerisinde LSD testine göre birbirinden istatistiksel olarak farksızdır 
göre ham protein oranı, uygulamalara bağlı olarak \% 11.0 ile \% 12.5 arasında değişmiş ve bu değişimin istatistiksel olarak önemli olduğu ortaya çıkmıştır. Paraquat+gübreleme ve Glyphosate+gübreleme uygulama parsellerinde ham protein oran ortalamas1, kontrol ve 2.4-D+gübreleme uygulama parsellerindekine göre önemli derecede daha yüksek olarak saptanmıştır. Kontakt etkili total bir herbisit olan Paraquat ve sistemik etkili bir total herbisit olan Glyphosate uygulama parsellerinde uygulama spot olarak yapılmış olmasına karşılık, uygulama alanı civarındaki bitkiler de herbisit uygulamasından etkilenmiştir. Paraquat uygulanan parsellerde toprak üstü organları etkilenen çok yıllık bitkilerin yeniden sürgün verdiği ve uygulama sonrası çimlenen bir y1llık bitkilerin hasat zamanında diğer parsellerdeki bitkilere göre daha genç ve taze durumda bulundukları gözlenmiştir. Glyphosate uygulama parsellerinde ise uygulama sonrası çimlenen bir yıllık bitkilerin hasat zamanında gelişmenin erken dönemlerinde bulunduğu gözlenmiştir. Açılanan nedenlerle, Paraquat+gübreleme ve Glyphosate+gübreleme parsellerinden hasat edilen otun ham proteiniçeriğinin kontrol ve 2,4-D+gübreleme parsellerinden hasat edilen otun ham protein içeriğine göre daha yüksek olduğu söylenebilir. Nitekim söz konusu parsellerde bitki yaşlanmasının göstergesi olan otun ADF ve NDF içeriklerinin istatistiksel olarak farklı olmasa da diğer parsellerdekine göre daha düşük olduğu saptanmıştır (Çizelge 4).

Araştırmada, ham protein oranı yıllara bağlı olarak önemli değişim göstermiştir. Denemenin üçüncü yılında ham protein oranı ortalaması diğer iki yıla göre istatistiksel olarak önemli derecede daha düşük olmuştur. $\mathrm{Bu}$ duruma neden olarak üçüncü yıl düşen aşırı yağışlardan dolayı hasadın geç yapılmış olması gösterilebilir. Birinci yıl 8 Mayıs 2007 de, ikinci y1l 30 Nisan 2008'de, üçüncü yıl 19 Mayıs 2009 da hasat yapılmıştır. Genel olarak ham protein oranlarındaki farklılık botanik kompozisyondaki değişiklikler ile ilgili (Gökkuş \& Koç 1996) olmasına rağmen araştırmamızda geç yapılan hasat ham protein oranının düşmesine yol açmıştır (Baytekin \& Gul 2009).

\subsection{Uygulamalarin ham protein verimine etkisi}

Uygulamalar ve yıllar ile bunların interaksiyonunun ham protein veriminde istatistiksel olarak önemli bir farklılık yaratmıştır (Çizelge 3). Çizelge 3'de izlendiği gibi, üç yıllık ortalamaya göre ham protein verimi uygulamalara bağlı olarak $9.1 \mathrm{~kg} \mathrm{da}^{-1}$ ile $24.6 \mathrm{~kg} \mathrm{da}^{-1}$ arasında değişmiştir. Biçim+gübreleme

\section{Çizelge 4- Farklı yabancı ot kontrol metodlarının merada saptanan ADF oranı (\%) ve NDF oranı (\%) ortalamaları ile SKMV $\left(\mathrm{kg} \mathrm{da}^{-1}\right)$ ortalamaları}

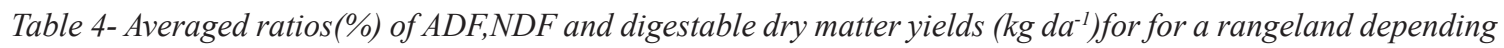
on the weed control method

\begin{tabular}{|c|c|c|c|c|c|c|c|c|c|c|c|c|}
\hline \multirow{2}{*}{ Uygulama } & \multicolumn{4}{|c|}{$A D F(\%)$} & \multicolumn{4}{|c|}{$N D F(\%)$} & \multicolumn{4}{|c|}{$S K M V\left(k g d a^{-1}\right)$} \\
\hline & 1.yll & $2 . y l l$ & $3 . y l l$ & Ort. & 1.ysl & $2 . y l l$ & $3 . y l l$ & Ort. & 1.ysl & $2 . y l l$ & 3.yll & Ort. \\
\hline Kontrol & 36.6 & 30.0 & 33.6 & 33.4 & 48.6 & 47.1 & 52.6 & $49.4 b c^{*}$ & $97.3 \mathrm{abc} *$ & $20.7 \mathrm{~b}$ & 71.9 & $63.3 \mathrm{c}$ \\
\hline Biçim+gübre & 33.1 & 27.3 & 36.0 & 32.1 & 51.5 & 50.3 & 56.2 & $52.7 \mathrm{bc}$ & $96.2 \mathrm{abc}$ & $141.8 \mathrm{a}$ & 134.5 & $124.2 \mathrm{ab}$ \\
\hline Gübre & 32.6 & 30.9 & 28.9 & 30.8 & 48.6 & 50.7 & 43.2 & $47.5 \mathrm{bc}$ & $145.8 \mathrm{a}$ & $121.7 \mathrm{a}$ & 176.0 & $147.9 \mathrm{a}$ \\
\hline 2.4-D+gübre & 34.1 & 33.9 & 37.2 & 35.0 & 51.1 & 56.6 & 61.8 & $56.5 \mathrm{ab}$ & $138.5 \mathrm{ab}$ & $104.3 \mathrm{a}$ & 131.0 & $124.6 \mathrm{ab}$ \\
\hline Pic+2.4-D+gübre & 31.0 & 31.3 & 39.9 & 34.1 & 57.0 & 54.5 & 66.5 & $59.3 \mathrm{a}$ & $84.2 \mathrm{bc}$ & $109.8 \mathrm{a}$ & 190.0 & $128.0 \mathrm{ab}$ \\
\hline Paraquat+gübre & 32.4 & 31.2 & 27.1 & 30.2 & 43.5 & 53.0 & 42.0 & $46.2 \mathrm{c}$ & $60.0 \mathrm{c}$ & $15.3 \mathrm{~b}$ & 160.1 & $78.5 \mathrm{bc}$ \\
\hline Glyphosate+gübre & 32.2 & 27.8 & 36.5 & 32.2 & 40.7 & 49.9 & 54.9 & $48.5 \mathrm{bc}$ & $42.9 \mathrm{c}$ & $22.0 \mathrm{~b}$ & 130.3 & $65.1 \mathrm{c}$ \\
\hline Ortalama & 33.1 & 30.4 & 34.2 & 32.6 & 48.7 & 51.7 & 53.9 & 51.4 & $95.0 \mathrm{~B}^{+}$ & $76.5 \mathrm{~B}$ & $142.0 \mathrm{~A}$ & 104.5 \\
\hline
\end{tabular}

*, aynı sütün içerisinde benzer harf ile gösterilen ortalamalar $\mathrm{P} \leq 0.05$ hata sinırları içerisinde Duncan testine göre birbirinden istatistiksel olarak farksızdır; +, aynı satır içerisinde benzer harf ile gösterilen ortalamalar $\mathrm{P} \leq 0.05$ hata sınırları içerisinde LSD testine göre birbirinden istatistiksel olarak farksızdır 
ve gübreleme uygulamaları ham protein verimini kontrole göre istatistiksel olarak önemli derecede artırmıştır. Denemenin ikinci yılında ham protein veriminin üçüncü y1la göre istatistiksel olarak daha düşük olduğu belirlenmiştir. Ham protein veriminin uygulamalara ve yıllara bağlı olarak değişimi, kuru madde veriminin uygulamalara bağlı olarak değişimine paralellik göstermiştir. $\mathrm{Bu}$ bulgular Gökkuş \& Koç (1996) ve Aydın \& Uzun (2000)'un bulguları ile uyum içersindedir.

\subsection{Uygulamalarin mera otunun ADF (Selüloz+Lignin) oranına etkisi}

Uygulamalar ve yıllar ADF oranlarında istatistiksel olarak önemli farklılıklar yaratmamıştır. Farklı uygulama parsellerinden her üç yılda hasat edilen ot örneklerinde saptanan ADF oranı ortalamaları Çizelge 4'de verilmiştir. Çizelge 4'de görüldüğü gibi uygulamalara bağlı olarak üç yılın ortalama ADF oranları \% 30.2 ile 35.0 arasında değişmiş ve bu değişimin istatistiksel olarak önemli olmadı̆̆ ortaya çıkmıştır.

\subsection{Uygulamalarin mera otunun NDF (Selüloz+Hemiselüloz+Lignin) oranına etkisi}

Uygulamalar NDF oranında istatistiksel olarak önemli bir fark yaratmış, yıllar ise NDF oranında istatistiksel olarak bir fark yaratmamıştır (Çizelge 4). Çizelge 4'de görüldüğ̈̈ gibi uygulamalara bağlı olarak üç yılın ortalaması NDF oranları \% 46.2 ile 59.3 arasında değişmiş ve bu değişimin istatistiksel olarak önemli olduğu saptanmıştır. Picloram+2.4$\mathrm{D}$ +gübreleme uygulamas1 otun NDF oranında kontrol uygulamasindakine göre istatistiksel olarak önemli derecede artışa neden olmuştur. Söz konusu herbisitlerin uygulandığ 1 parsellerde vejetasyonun büyük ölçüde buğdaygillerden oluşması nedeniyle (Çizelge 3) bu uygulamada NDF oranının yüksek olması beklenen bir sonuçtur. Çünkü buğdaygillerin özellikle hemiselüloz oranları geniş yapraklı bitkilere göre daha yüksektir (Pearson \& Ison 1987). Paraquat + gübreleme parsellerinde otun NDF içeriğinin 2.4-D+gübreleme ve 2.4-D+Picloram+gübreleme uygulama parsellerindekine ve Glyphosate+gübreleme parsellerinde ise ve 2.4-D+Picloram+gübreleme parsellerindekine göre istatistiksel olarak önemli derecede daha düşük olduğu saptanmıştır. Bu duruma neden olarak, söz konusu parsellerde buğdaygil oranının düşük olması yanında, ham protein oranı ile ilgili bulguların açıklanmasında da belirtildiği gibi bu parsellerde hasat zamanında bitkilerin daha erken gelişme döneminde bulunması gösterilebilir.

\subsection{Uygulamaların sindirilebilir kuru madde verimine etkisi}

Uygulamalar ve yıllar ile uygulama $x$ y1l interaksiyonu, sindirilebilir kuru madde veriminde istatistiksel olarak önemli derecede farkl1lık yaratmıştır. Farklı uygulama parselleri için saptanan sindirilebilir kuru madde verimi ortalamaları Çizelge 4'de verilmiştir. Araştırmanın birinci yılında uygulamalar sindirilebilir kuru madde veriminde kontrole göre istatistiksel olarak önemli bir farklılık yaratmamış, gübre ve 2.4-D+gübre uygulamaları Paraquat+gübreleme ve Glyphosate+gübreleme uygulamalarına göre istatistiksel olarak önemli derecede daha yüksek sindirilebilir kuru madde verimi sağlamıştır. İkinci yılda ise, Paraquat ve Glyphosate uygulamaları dışındaki tüm uygulamalar kontrole göre sindirilebilir kuru madde veriminde önemli derecede artışa neden olmuştur. Üçüncü yılda, uygulamalar arasında sindirilebilir kuru madde verimi açısından istatistiksel olarak önemli fark çıkmamıştır. Üç yıllık ortalama değerlere göre, Paraquat ve Glyphosate uygulamaları dışındaki uygulamalar kontrole göre sindirilebilir kuru madde veriminde önemli artışa neden olmuştur. Söz konusu uygulama parsellerinden elde edilen otun ADF içeriği düşük olması nedeniyle sindirilebilir kuru madde oranlarının düşük olmasına karşılık, kuru madde veriminin düşük olması nedeniyle bu uygulama parsellerinde sindirilebilir kuru madde veriminin düşük olması beklenen bir sonuçtur.

\section{Sonuçlar}

Araştırma sonuçları, Çukurova Bölgesinde makiliklerin değişik düzeylerde tahribi sonucu ortaya çıkan otsu vejetasyona sahip meralarda bulunan çalımsı ve dikensi türlerin kontrolünde biçim, gübreleme 2.4-D veya Picloram+2.4-D uygulaması gibi uygulamalar meranın kuru madde 
veriminde ve sindirilebilir kuru madde veriminde kontrole göre önemli derecede artışa neden olmuş, Paraquat ve Glyphosate gibi total herbisitler ise meranın kuru madde verimi ve sindirilebilir kuru madde veriminde kontrole göre önemli bir farklılık yaratmamıştır. Araştırmadan elde edilen bulgulara dayanarak, Çukurova bölgesindeki makilerin tahribi sonucu ortaya çıkmış meralarda çoğunluğu geniş yapraklı bitkilerden oluşan yabancı otların Picloram+2.4-D uygulamasıyla etkin bir şekilde kontrol edilebileceği, bu tip meralarda yabanc1 ot kontrolü ile birlikte yapılacak gübre uygulamasının meranı ot verimi ve kalitesinde artışa neden olacağ 1 söylenebilir.

\section{Teşekkür}

Araştırma TÜBİTAK TOVAG tarafından desteklenen $106 \mathrm{O} 585$ numaralı projenin bir bölümüdür. TÜBİTAK'a sağladığı finansal destek nedeniyle teşekkür ederiz.

\section{Kaynaklar}

Altın M (1992). Çayır Mera Islahı. Trakya Üniversitesi Tekirdağ Ziraat Fakültesi, Yayın No: 152, Ders Kitabı: 13, T.Ü. Tekirdağ Ziraat Fakültesi Basımevi, Tekirdağ

Altın M, Gökkuş A \& Koç A (2005). Çayır Mera Islahı, TÜGEM, s.468, Ankara

Altın M, Gökkuş A \& Koç A (2011). Çayır ve Mera Yönetimi 1. Cilt. Tarım ve Köyişleri Bakanlığı TÜGEM Çayır-Mera Yembitkileri ve Havza Geliştirme Daire Başkanlığı, Ankara

Ankom ( 2009). Method for determining acid detergent fiber and neutral detergent fiber. www.ankom.com (Erişim tarihi: 15 Ağustos 2009)

Aydın İ \& Uzun F (2000). Ladik ilçesi salur köyü merasında farklı 1slah metodlarının ot verimi ve botanik kompozisyon üzerine etkileri. Turkish Journal of Agricultural Forestry 24: 301-307

Bakır O (1985). Çayır-Mer'a Islahı. Prensip ve Uygulamalar. Ankara Üniversitesi Ziraat Fakültesi Yayınları : 947, Ders Kitab1: 272, Ankara, s. 76-102

Baytekin H \& Gül İ (2009). Yem bitkilerinde hasat, kuru ot verimi ve depolama yem bitkileri, (Ed: R Avcığlu, R Hatipoğlu , Y Karadağ), Cilt III, TÜGEM, Emre Basımevi, İzmir, s. 121-14
Bovey RW, Meyer RE \& Morton HL (1972). Herbage Production Following Brush Control With Herbicides in Texas. Journal of Range Management 22(5): 315317

Bulgurlu Ş \& Ergül M (1978). Yemlerin Fiziksel, Kimyasal ve Biyolojik Analiz Metotları. Ege Üniversitesi Ziraat Fakültesi Yayınları No: 127, Ege Üniversitesi Matbaası, Bornova, İzmir

Çınar S, Hatipoğlu R \& Avcı M (2003). Adana ili Tufanbeyli ilçesi Hanyeri köyü merasında verim ve botanik kompozisyonun saptanması üzerine bir araştırma. Türkiye 5. Tarla Bitkileri Kongresi, 13-17 Ekim 2003, Diyarbakır, Cilt I, s. 352-356

Çınar S, Hatipoğlu R, Avcı M \& İnal I (2009). 4342 Sayılı Mera Kanunu Kapsamında Çukurova Tarımsal Araştırma Enstitüsü Ve Ç.Ü. Ziraat Fakültesi Koordinatörlüğünde Yürütülen Mera Islahı ve Amenajman Uygulama Projeleri. Türkiye VIII. Tarla Bitkileri Kongresi, 19-22 Ekim 2009, Hatay, Cilt I: s. 579-5583

Çınar S, Hatipoğlu R, Avcı M, İnal İ, Aydemir S K \& Yücel H (2011). Çukurova'nın Geçit Kesimi Meralarında Yabancı Ot Mücadelesi Üzerine Bir Araştırma. IX. Türkiye Tarla Bitkileri kongresi, 12-15 Eylül 2011, Bursa, Cilt III, s. 1674-1679

Darrell L D \& Leon W (2005). Weed control in pasture\&range, College of Agriculture \& Biological Sciences. Cooperative Extension Service. South Dakota State University

Düzgüneş O, Kesici T, Kavuncu O \& Gürbüz F (1987). Araştırma ve Deneme Metodları, Ankara Üniversitesi Ziraat Fakültesi Yayınları, No: 295, Ankara

Gonzalez R, Medrano C, Gutierrez W, Esparza D, Anez D, Montiel M \& Orono J (1997). Facultad de Ciencias Veterinarias, Universidad del Zulia, Aspartado 526 Maracaibo, Estado Zulia, Venezuela

Gokkuş A (1991). Doğu ve Güney Doğu Anadolu Bölgeleri Çayır Mera ve Yem Bitkileri ve Hayvancılığg Geliştirme Projesi Eğitim Semineri. 20-22 Şubat 1991, Erzurum

Gökkuş A \& Koç A (1996). Farklı zamanlarda uygulanan değişik herbisitlerin çayırların verim ve botanik kompozisyonlarına etkileri, Journal of Agriculture and Forestry 20: 305-308

Gökkuş A \& Koç A (2001). Mera ve Çayır Yönetimi. Atatürk Üniversitesi Ziraat Fakültesi Ders Yayınları No: 228 
Hatipoğlu R, Avci M, Kilicalp N, Tukel T, Kokten K \& Çınar S (2001). Çukurova Bölgesindeki Taban Bir Merada Fosforlu Gübreleme Ve Farklı Azot Dozlarının Ot Verimi Ve Kalitesi İle Botanik Kompozisyona Etkileri Üzerinde Bir Araştırma, Türkiye IV. Tarla Bitkileri Kongresi, 17-21 Eylül 2001, Tekirdağ, Cilt III, s. 1-6

İnal I, Avcı M, Çınar S, Yücel C, Hatipoğlu R \& Avag (2011). Çukurova Bölgesi Sahil Meralarının Vejetasyon Yapısı Üzerine Bir Araştırma. IX. Türkiye Tarla Bitkileri Kongresi, 12-15 Eylül 2011, Bursa, Cilt III, s.1664-1667

Jacobs J S \& Sheley R L (1999). Spotted knapweed, forbs and grass response to 2.4-D and N-fertilizer. Journal of Range Management 52: 482-488

MDM (2009). Meteorological data for Mersin, www. wunderground.com (Acces date: 2010)

Nichols J T \& Mc Murphy W E (1969). Range Recovery and Production as İnfluenced by Nitrogen and 2.4-D Treatments. Journal of Range Management 1: 116119

Özaslan A (1996). The effects of ripping, nitrogen and herbicide applications on improvement of vegetation in Erzurum pastures. Ataturk University, Department of Field Crops, Master Thesis (Unpublished), Erzurum, pp. 1- 54

Pearson C J \& Ison P L (1987). Agronomy of Grassland Systems. CAmbridge University Press, Cambridge

Rodney G L (2000). Leafy Spurge (Euphorbia esula) Control With Glyphosate Plus 2.4-D. Journal of Range Management 53:68-72

Roger L S, Celestine A D, Mary B H \& James S J (2000). Spotted knapweed and grass response to herbicide treatments. Journal of Range Management.Society for Range Management. Volume 53: 176-182

Sheaffer C C, Peterson M A, McCalın M, Volene J J, Cherney J H, Johnson K D, Woodward W T \& Viands D R (1995). Acid Detergent Fiber, Neutral Detergent Fiber Concentration and Relative Feed Value, North American Alfalfa İmprovement Conference, Minneapolis

TAN (1995). The determination of nitrogen according to kjeldahl using block digestion and steam distilation. Tecator Application Note AN 300, Tecator AB Sweden, pp. 1-11

TBLK (2007). Ç.Ü. Ziraat Fakültesi Toprak Bölümü Laboratuarı kayıtları, Adana

Thilenius J F, Smith D R \& Brown G R (1974). Effect of 2.4-D on Composition and Production of an Alpine Plant Community in Wyoming. Journal of Range Management 27(2): 140-142

Tükel T, Hatipoğlu R, Hasar E, Çeliktaş N \& Can E (1996). Azot ve Fosfor Gübrelemesinin Çukurova Bölgesinde Tüylü Sakalotu'nun (Hyparrhenia hirta (L.) Stapf) Dominant Olduğu Bir Mer'anın Verim ve Botanik Kompozisyonuna Etkisi Üzerinde Bir Araştırma. Türkiye 3. Çayır-Mer'a Yem Bitkileri Kongresi, 17-19 Haziran 1996, Erzurum, s. 59-65

Van Soest P J (1985). Composition, fiber quality, and nutritive value of forages. (E. Heath, F. Barnes, S. Metcalfe eds.). Forages, Iowa State University Press, Iowa, s. 412-421

Vallentine J F (1989). Range Development and Improvements, Academic Pres Inc. New York, s. 523 